\title{
The influence of age and the reproductive status to the blood indicators of the ewes
}

\begin{abstract}
The influence of age and the reproductive status has been researched in the blood serum of 75 Merinolandschaf ewes. We have detected statistically very high concentrations of $\mathrm{Ca}$ in the blood serum of pregnant and nonpregnant ewes comparing to those in lactation, while the opposite way has been noticed for the concentrations of P-inorganic and Na. Statistically much higher concentrations of $\mathrm{K}$ have been found in the lactating and nonpregnant ewes comparing to the pregnant ones. Statistically much higher concentrations of albumin and cholesterol have been detected in the blood of pregnant ewes comparing to the non-pregnant ones, while the opposite way has been noticed for the concentrations of total proteins. GGT activity was statistically much higher in the blood of ewes in lactation comparing to the non-pregnant ones and the CK and ALT activity in the pregnant ones comparing to those in lactation. The ewes up to one year old had statistically very significant high concentrations of P-inorganic, Na, Fe, glucose, AP, GGT, CK activities and in the older ewes the concentrations of cholesterol and total proteins. Due to that, it is necessary to, before the metabolic profile specification of ewes, take into consideration age and the reproductive status of the animals. For the age there have to be taken the concentrations of P-inorganic, Na, Fe, glucose, cholesterol and total proteins as well as AP, GGT, CK activities and for the reproductive status the concentrations of $\mathrm{Ca}$, P-inorganic, $\mathrm{Na}$, albumin, total proteins as well as the ALT, CK, GGT activities. These researches give basis for the regular therapy application and carrying out the prevention of the metabolic disturbances of ewes in the aim of reducing economy losses.
\end{abstract}

Key Words: ewe, age, reproductive status, blood

\section{Zusammenfassung}

Titel der Arbeit: Einfluss des Alters, der Trächtigkeit und der Laktation auf Blutindikatoren bei Schafen Bei 75 Merinolandschafen wurde der Einfluss des Alters, der Trächtigkeit und der Laktation auf Blutinhaltstoffe untersucht. Erfasst wurden ausgewählte Makro- und Mikroelemente, biochemische Indikatoren und Enzyme. So konnten signifikant höhere Ca Konzentrationen im Blutserum bei nicht tragenden und tragenden Tieren gegenüber laktierenden Tieren nachgewiesen werden. Umgekehrte Verhältnisse fanden sich bei organischem P und Na. Signifikant höhere Konzentrationen von Albumin und Cholesterin ergaben sich bei tragenden gegenüber nicht tragenden Schafen, umgekehrte Verhältnisse fanden sich beim Gesamteiweiß. Tragende Schafe hatten signifikant höhere Konzentrationen bei GGT gegenüber nicht tragenden, und höhere Aktivitäten von CK und ALT gegenüber laktierenden. Signifikant höhere Konzentrationen bei Schafen im Alter bis zu einem Jahr wurden für organischen P, Na, Fe, der Glykose, der Aktivität von AP, GGT und CK, bei älteren Tieren dagegen bei Cholesterin und Gesamteiweiß festgestellt. Die Ergebnisse zeigen, dass bei der Erfassung des metabolischen Profils das Alter sowie der reproduktive Zustand der Tiere zu berücksichtigen sind. Hinweise für die Bedeutung und Erfassung der einzelnen Blutinhaltsstoffe werden diskutiert. Die Ergebnisse belegen die Notwendigkeit und Möglichkeit prophylaktischer und therapeutischer Maßnahmen bei Stoffwechselstörungen von Schafen zur Vermeidung ökonomischer Verluste.

Schlüsselwörter: Schafe, Alter, reproduktiver Status, Blut

\section{Introduction}

Knowing the metabolic profile of the ewes, including serum mineral and biochemical indicators, is important to specify the feed status as well as to prevent health disorders which lead to the production and reproduction disturbance. A significant number of 
authors describe the mineral and biochemical indicators in the blood of the sheep (PASTRANA et al. 1991a, b; SHINDE et al. 1995; KLINKON and ZADNIK, 1997). But, only a very small number of authors report about the influence of age and the reproductive status as the important perequisites for the biochemical indicators' interpretation in sheep (BAUMGARTNER and PENTHANER, 1994; RAMOS et al., 1994; EL-SHERIF and ASSAD, 2001; ANTUNOVIC et al., 2002). In order to establish the metabolic profile of the sheep it is necessary to know the influence of age as well as the reproductive status. The fact is that out of the earlier mentioned literature it is not possible to draw any significant conclusions; therefore the aim of this research is to show the changes of the serum mineral and biochemical indicators in the blood of ewes depending on age and the reproductive status.

\section{Material and methods}

Biological investigations were carried out on 75 Merinolandschaf ewes. The influence of the reproductive status has been tested in the blood serum of 45 ewes (15 pregnant ewes on the 20th day prior to lambing, 15 lactating ewes on the 30th day of the lactation and 15 non-pregnant ewes). The ewes were in average 2 and 3 years old, healthy and in a good physical condition.

The influence of age in the blood serum of 30 sheep (15 sheep from 3 and 15 sheep younger than 1 year).

The sheep have been on pastures (Lolium perene, Lolium italicum, Phleum phleoides, Trifolium repens and Dactylis glomerata) and had meadow hay at offer. Pregnant ewes and ewes in lactation had a daily fed of $300 \mathrm{~g}$ a grain mixture $(60 \%$ oat, $30 \%$ maize and $10 \%$ soybean grits). All ewes were given salt licks and fresh water (ad libitum). The blood was collected from the jugular vein $(10 \mathrm{ml})$ into the sterile vacuum tubes Venoject ${ }^{\circledR}$ (Sterile Terumo Europe, Leuven, Belgium). After that, the serum was separated by centrifugation $(10 \mathrm{~min})$ at 3000 revolutions/min and placed into the Boehringen Mannheim/Hitachi 911 auto analyser (Boehringer Mannheim GmbH, Mannheim, Germany). Within the blood serum there have been found the concentrations of the mineral indicators (Ca-Calcium, P-inorganic Phosphorus, KPotassium, Na-Sodium, Cl-Chloride, Fe-Iron and Se-Selenium), concentrations of the biochemical indicators (albumin, bilirubin-total, glucose, urea, cholesterol and total proteins) and enzyme activity (ALT-alanine aminotransferase, AST-aspartate aminotransferase, alpha-amylase, AP-alkaline phosphatase, CK-creatine kinase, GGT$\gamma$-glutamyl transferase, cholinesterase and LDH-lactate dehydrogenase).

The results (mean $-\bar{x}$ and standard deviation $-\mathrm{s}$ ) were statistically evaluated using descriptive statistical procedures, and the significance of all between - group differences was checked by ANOVA according to STATISTICA (StatSoft, Inc. 2001). Differences were considered as significant at the level of 0.05 or less.

\section{Results}

Significant variations of the mineral indicators in blood of the ewes depending on the reproductive status could be seen in the Table 1 .

The concentrations of Ca were statistically much higher $(\mathrm{P}<0.01)$ in the blood serum of pregnant and non-pregnant ewes comparing to the ewes in lactation while the opposite way has been detected for the concentrations of P-inorganic and $\mathrm{Na}$. 
Statistically significant higher concentrations $(\mathrm{P}<0.01)$ of $\mathrm{K}$ have been marked in the lactating and non-pregnant ewes comparing to the pregnant ones, while the concentrations of Se have been statistically very significantly higher $(\mathrm{P}<0.05)$ in the pregnant ewes comparing to the lactation ewes.

Table 1

Mineral indicators of ewes depending on the reproductive status (Mineralische Indikatoren der Schafe bei unterschiedlichem reproduktivem Status)

\begin{tabular}{|c|c|c|c|c|c|c|}
\hline \multirow[t]{3}{*}{ Indicator } & \multicolumn{6}{|c|}{ Reproductive status } \\
\hline & \multicolumn{2}{|c|}{ Pregnant - a } & \multicolumn{2}{|c|}{ Lactating - b } & \multicolumn{2}{|c|}{ Non-pregnant- c } \\
\hline & $\bar{X}$ & $\mathrm{~s}$ & $\bar{x}$ & $\mathrm{~S}$ & $\bar{x}$ & $\mathrm{~s}$ \\
\hline $\mathrm{Ca}, \mathrm{mmol} / \mathrm{l}$ & $2.37^{* * \mathrm{~b}}$ & 0.26 & 2.01 & 0.30 & $2.42^{* * b}$ & 0.21 \\
\hline P-inor., $\mathrm{mmol} / \mathrm{l}$ & 1.59 & 0.19 & $2.29^{* * a, c}$ & 0.34 & 1.64 & 0.21 \\
\hline $\mathrm{K}, \mathrm{mmol} / \mathrm{l}$ & 4.22 & 0.30 & $4.98^{* * a}$ & 0.39 & $4.96^{* * a}$ & 0.23 \\
\hline $\mathrm{Na}, \mathrm{mmol} / \mathrm{l}$ & 138.33 & 4.24 & $146.93^{* * a, c}$ & 5.56 & 141.53 & 4.14 \\
\hline $\mathrm{Cl}, \mathrm{mmol} / \mathrm{l}$ & 102.67 & 5.24 & 104.33 & 2.67 & 103.47 & 3.45 \\
\hline $\mathrm{Fe}, \mu \mathrm{mol} / \mathrm{l}$ & 22.68 & 3.91 & 22.45 & 2.04 & 23.12 & 3.24 \\
\hline $\mathrm{Se}, \mathrm{mg} / \mathrm{kg}$ & $0.04^{* b}$ & 0.016 & 0.02 & 0.018 & 0.03 & 0.016 \\
\hline
\end{tabular}

** $(\mathrm{P}<0.01) ; *(\mathrm{P}<0.05)$

Analysis of the biochemical indicators (see Table 2) has shown significant changes of the most indicators depending on age and the reproductive status.

Table 2

Biochemical indicators of ewes depending on the reproductive status (Biochemische Indikatoren der Schafe bei unterschiedlichem reproduktivem Status)

\begin{tabular}{|c|c|c|c|c|c|c|}
\hline \multirow[t]{3}{*}{ Indicator } & \multicolumn{6}{|c|}{ Reproductive status } \\
\hline & \multicolumn{2}{|c|}{ Pregnant- a } & \multicolumn{2}{|c|}{ Lactating - b } & \multicolumn{2}{|c|}{ Non-pregnant -c } \\
\hline & $\bar{x}$ & $\mathrm{~s}$ & $\bar{x}$ & $\mathrm{~s}$ & $\bar{x}$ & $\mathrm{~s}$ \\
\hline Abumin, g/l & $28.10^{* * i c}$ & 1.87 & $30.31^{* * a, c}$ & 1.79 & 24.73 & 2.08 \\
\hline Bilirubin-total, $\mu \mathrm{mol} / \mathrm{l}$ & $5.67^{* *} \mathrm{c}$ & 1.29 & $5.63^{* * c}$ & 1.23 & 3.87 & 1.51 \\
\hline Glucose, mmol/l & 3.04 & 0.86 & 3.09 & 0.77 & 3.65 & 0.76 \\
\hline Urea, $\mathrm{mmol} / \mathrm{l}$ & 6.84 & 2.29 & 5.48 & 1.95 & $7.39^{* b}$ & 2.27 \\
\hline Cholesterol, mmol/l & $1.59^{*_{c}}$ & 0.21 & 1.49 & 0.21 & 1.31 & 0.37 \\
\hline Total protein, g/l & 67.41 & 9.56 & 64.26 & 7.22 & $76.60^{* *_{a}, \mathrm{~b}}$ & 11.65 \\
\hline
\end{tabular}

The concentrations of albumin within the blood of the lactating ewes have been statistically much higher $(\mathrm{P}<0.01)$ comparing to the pregnant and non-pregnant ewes as well as significantly higher $(\mathrm{P}<0.01)$ in the pregnant comparing to the non-pregnant ewes.

In the blood of the pregnant and the lactating ewes statistically notable higher concentrations $(\mathrm{P}<0.01)$ of the total bilirubin have been found comparing to the nonpregnant ewes. Statistically notable higher concentrations $(\mathrm{P}<0.05)$ of the cholesterol have been found in the blood of the pregnant ewes comparing to the non-pregnant ones. The concentrations of the total proteins have been statistically higher $(\mathrm{P}<0.01)$ in the non-pregnant ewes comparing to the pregnant ones and those in lactation.

The enzyme activity in the blood of the ewes depending on the reproductive status is shown in the Table 3.

As it has been shown in the Table 3, the activity of GGT has been statistically much higher $(\mathrm{P}<0.01)$ in blood of the ewes in lactation comparing to the pregnant and nonpregnant ewes. Also, there has been found statistically much higher acivity of CK $(\mathrm{P}<0.01)$ in non-pregnant ewes and statistically higher ALT activity in the pregnant ewes comparing to those in lactation. The activity of AP, $\alpha$-amilase, AST, 
cholinesterase and LDH within the blood of the ewes had no statistically notable differences $(\mathrm{P}>0.05)$ depending on the reproductive status. As it has been shown in the Table 4., statistically much higher concentrations have been established $(\mathrm{P}<0.01)$ of the P-inorganic, $\mathrm{Na}$ and $\mathrm{Fe}$ within the ewes younger than 1 year comparing to the older ewes.

Table 3

The enzyme activity in the blood of the ewes depending on the reproductive status (U/l) (Enzymaktivität im Blut der Schafe bei unterschiedlichem reproduktivem Status)

\begin{tabular}{lcccccc}
\hline Indicator & \multicolumn{2}{c}{ Pregnant- $\mathrm{a}$} & \multicolumn{2}{c}{ Reproductive status } & \multicolumn{2}{c}{ Lactating $-\mathrm{b}$} \\
& $\bar{x}$ & $\mathrm{~s}$ & $\bar{x}$ & $\mathrm{~s}$ & $\bar{x}$ & $\mathrm{~s}$ \\
\hline ALT & $23.60^{* \mathrm{~b}}$ & 4.88 & 19.07 & 3.99 & 21.27 & 3.22 \\
AP & 199.20 & 95.88 & 150.47 & 86.67 & 153.67 & 89.57 \\
Alpha amylase & 20.60 & 8.85 & 19.87 & 6.78 & 16.67 & 10.04 \\
AST & 104.87 & 17.95 & 102.73 & 16.39 & 106.60 & 19.86 \\
CK & 61.93 & 17.45 & 50.43 & 15.20 & $73.20^{* * b}$ & 18.57 \\
GGT & 45.27 & 8.50 & $77.73^{* * a, c}$ & 9.82 & 41.40 & 6.96 \\
Cholinesterase & 141.32 & 26.18 & 137.87 & 18.68 & 139.33 & 20.88 \\
LDH & 469.87 & 72.48 & 493.40 & 84.97 & 509.80 & 93.04 \\
\hline
\end{tabular}

** $(\mathrm{P}<0.01) ; *(\mathrm{P}<0.05)$

Table 4

Mineral indicators of the ewes depending on the age (Mineralische Indikatoren in Abhängigkeit vom Alter der Schafe)

\begin{tabular}{lcccc}
\hline Indicator & \multicolumn{2}{c}{ Age } & \multicolumn{2}{c}{$<1$ years } \\
& $\bar{x}$ & $\mathrm{~s}$ years & $\bar{x}$ & $\mathrm{~s}$ \\
\hline $\mathrm{Ca}, \mathrm{mmol} / \mathrm{l}$ & 2.39 & 0.25 & 2.44 & 0.19 \\
$\mathrm{P}-\mathrm{inor} ., \mathrm{mmol} / \mathrm{l}$ & 1.43 & 0.20 & $2.74^{* *}$ & 0.17 \\
$\mathrm{~K}, \mathrm{mmol} / \mathrm{l}$ & 4.89 & 0.82 & $5.61^{*}$ & 0.64 \\
$\mathrm{Na}, \mathrm{mmol} / \mathrm{l}$ & 137.93 & 3.57 & $148.93^{* *}$ & 3.55 \\
$\mathrm{Cl}, \mathrm{mmol} / \mathrm{l}$ & 104.33 & 2.99 & 105.34 & 2.50 \\
$\mathrm{Fe}, \mu \mathrm{mol} / \mathrm{l}$ & 23.59 & 1.86 & $28.92^{* *}$ & 1.61 \\
$\mathrm{Se}, \mathrm{mg} / \mathrm{kg}$ & 0.04 & 0.015 & 0.03 & 0.016 \\
\hline
\end{tabular}

$* *(\mathrm{P}<0.01) ; *(\mathrm{P}<0.05)$

In the Table 5 we have presented the average concentrations of the biochemical indicators within the blood of the ewes depending on their age.

Table 5

Biochemical indicators of the ewes depending on their age (Biochemische Indikatoren in Abhängigkeit vom Alter der Schafe)

\begin{tabular}{lcccc}
\hline Indicator & \multicolumn{2}{c}{ Age } & \multicolumn{2}{c}{$<1$ years } \\
& $\bar{x}$ & $\mathrm{~s}$ & $\bar{x}$ & $\mathrm{~s}$ \\
\hline Abumin, g/l & 25.63 & 4.21 & 29.38 & 5.98 \\
Bilirubin-total, $\mu \mathrm{mol} / \mathrm{l}$ & 3.87 & 0.99 & 3.73 & 1.33 \\
Glucose, mmol/l & 2.88 & 0.52 & $3.66^{* *}$ & 0.55 \\
Urea, mmol/l & 7.19 & 2.79 & 8.71 & 1.96 \\
Cholesterol, mmol/l & 1.27 & 0.12 & $1.01^{* *}$ & 0.07 \\
Total protein, g/l & 77.40 & 8.11 & $69.33^{* *}$ & 4.67 \\
\hline
\end{tabular}

** $(\mathrm{P}<0.01)$

Statistically notable higher $(\mathrm{P}<0.01)$ concentrations of the cholesterol and the total proteins have been found within the ewes older than 3 , while the concentrations of the glucose have been higher within the younger ewes. 
Analysing the influence of age to the enzyme activity (see Table 6) we can see a statistically very notable higher actvity of AP and GGT $(\mathrm{P}<0.01)$ and a statistically much higher activity of $\mathrm{CK}(\mathrm{P}<0.05)$ in the ewes younger than one year comparing to the older ones.

Table 6

The activity of enzymes in the blood of ewes depending on their age (U/l) (Enzymaktivität im Blut in Abhängigkeit vom Alter der Schafe (U/l))

\begin{tabular}{lcccc}
\hline Indicator & \multicolumn{2}{c}{ Age } & \multicolumn{2}{c}{$<1$ years } \\
& $\bar{x}$ & $\mathrm{~s}$ years & $\bar{x}$ & $\mathrm{~s}$ \\
\hline ALT & 23.20 & 3.57 & 25.33 & 3.24 \\
AP & 183.33 & 35.92 & $269.87^{* *}$ & 30.81 \\
Alpha amylase & 17.33 & 4.97 & 16.07 & 3.39 \\
AST & 101.40 & 15.31 & 112.53 & 19.01 \\
CK & 81.73 & 25.65 & $106.09^{*}$ & 18.84 \\
GGT & 41.27 & 5.29 & $68.20^{* *}$ & 7.52 \\
Cholinesterase & 144.00 & 14.05 & 142.00 & 10.92 \\
LDH & 507.13 & 103.34 & 582.07 & 107.12 \\
\hline$* *(\mathrm{P}<0.01) ; *(\mathrm{P}<0.05)$ & & & &
\end{tabular}

\section{Discussion}

Taking the reproductive status into consideration, there have been detected statistically much higher concentrations of $\mathrm{Ca}$ in the blood of the non-pregnant ewes in comparison to the lactating ones. This can be related to risks associated with parturition hypocalcemia in ruminants (KANEKO, 1997). YANO et al. (1991) have established that over the pregnancy the needs for $\mathrm{Ca}$ are increased in parallel with increase of the $\mathrm{Ca}$ absorption in the intestines. Lower concentrations of the P-inorganic have been detected in the blood of the pregnant ewes comparing to those in lactation. Lower inorganic serum $\mathrm{P}$ concentrations in the summer during the late pregnancy of ewes which are likely a consequence of lower concentrations of green herbage from the natural pastures, resulting in the lower intake. The lowest concentrations of $\mathrm{Na}$ were detected in the ewes in a high stage of pregnancy. These changes are in proportion with OKAB et al. (1992) who reported that the levels in blood plasma showed gradual decrease with the advance of pregnancy, with the lowest values occurring in the late stage. The lowest concentrations of $\mathrm{K}$ have been detected in the blood of the pregnant ewes. On the other hand, blood K concentrationin pregnant ewes was to be related to the metabolism disorders possibly occurring at the end of pregnancy - which in turn may lead to diverse pathologic deviations of metabolites in the blood (ANTUNOVIC et al., 2002). The highest concentrations of Se have been detected in the blood of the pregnant ewes and the lowest ones in those in lactation. This can be connected to the increased extraction of Se in milk or the lower concentration of it in food. WHITE et al. (1995) have detected in the ewes on a pasture a lower level of Se which could be the consequence of a shortage of this mineral in food.

In regard to the influence of the reproductive status, the ewes in lactation have had a statistically much higher concentrations of albumin in blood comparing to the pregnant and non-pregnant ewes. It is known that the albumins are a very important source of aminoacids for the necessities of the fetus and the mother (JAINUDEEN and HAFEZ, 1989). Similar concentrations of albumin in blood of the pregnant ewes and those in lactation have been found by CASTILLO et al. (1997). In our researches statistically 
higher concentrations of protein in total have been detected in the non-pregnant ewes comparing to the pregnant ones and those in lactations. Decrease of total protein over the pregnancy and lactation could be explained by a rapid extraction of imunoglobuline from the plasma during the last few months of pregnancy when a colostrum is being formed in the mammary gland (KANEKO, 1997) as well as the increased needs for proteins for the fetus development (CASTILLO et al., 1997).

Valuable indicators of protein and energy status in ewes are the concentration of urea, glucose and cholesterol in the blood (ANTUNOVIC et al., 2001). The highest levels of urea in this research have been detected with non- pregnant ewes. The same observations have been made by BAUMGARTNER and PERTHANER (1994) and HAMADEH et al. (1996). LÖHLE (1992) determined similar trend for concentrations of urea in the blood plasma of pregnant and lactation goats. Lower levels of glucose in blood of the pregnant ewes show that a fetus has an increased need for glucose due to the increased development in the last stage of pregnancy (HAMADEH et al., 1996). It is known that the needs for glucose after lambing excel the needs during the pregnancy (CASTILLO et al., 1999) which can be the reason of an increased milk production which implies the mobilisation of glucose for a lactosis production (McNEILL et al., 1998). RAMOS et al. (1994) have detected the increase of the total bilirubin in the blood of the pregnant ewes and those in lactation comparing to the non-pregnant ones as well as we have found in our researches. This could be the reason of the increased liver metabolism in those stages (KANEKO, 1997) and also the liver size and enzyme activity in lactation (MILLIGAN et al., 1986). Higher concentrations of cholesterol in the blood of the ewes during pregnancy and lactation comparing to the non-pregnant ewes have been detected by RAMOS et al. (1994). This could be a consequence of a heavier transport of the lypoproteins or energy deficiency in a meal.

Statistically much higher ALT activity has been detected in the blood of pregnant ewes comparing to the non-pregnant ones and those in lactation. The activity of protein metabolic enzymes ALT and AST in the animals feeding on plants is low and could be connected with the concentration of the total protein in blood (BARANOWSKI, 1995). The highest ALT activity has been found in the serum of the ewes in lactation, though without any significant differences $(\mathrm{P}>0.05)$. RAMOS et al. (1994) have had the same AST activity, mostly in the serum of the ewes in lactation and the drop towards the end of pregnancy which could be explained by greater liver weight. Higher AST activity could point to the deficit of proteins and an extra fat in the energy supply, about the greater metabolic activity of the liver and a greater physical activity of ewes (moving on the pasture). BARANOWSKI and KMIEC (1997) have detected a higher AST activity in the high stage pregnancy ewes comparing to the non-pregnant ewes. Celullar membranes of the hepatocytes have a greater pasage at that time which shows the greater detox function in the liver of the pregnant ewes. In the blood of the pregnant ewes there has been detected a higher AP activity comparing to the nonpregnant ones and those in lactation, though without any significant differences. Similar results have been obtained by ALONSO et al. (1997) and the authors quote it could be from about half way through pregnancy, there is a major adjustment of bone from the fetal skeleton. The lowest CK activity and the lowest concentration of Se in blood of ewes in lactation could be in connection. Nutritional vitamin E and Selenium deficiency myopathies result in muscle membrane instability and release of CK into the serum. SMITH et al. (1994) have pointed out that in the absence of exercise 
induced changes in otherwise clinically normal sheep and cattle, elevated total serum CK activity suggests a tentative diagnosis of vitamin E and Se deficiency.

The highest GGT activity in the blood of the ewes in lactation has been also found by RAMOS et al. (1994) and it is important in mammary gland because GGT are included in the hepatic enzyme profile. Ewe and cow colostrum contain a large amount of GGT and the colostral antibodies are transferred across the neonate's intestinal wall into the plasma (KANEKO, 1997).

Taking age into consideration the concentrations of Ca did not have any significant differences although there have been found higher concentrations in the blood of the ewes younger than 1 year. Similar results have been obtained by BAUMGARTNER and PERTHANER (1994). The P-inorganic concentration drop in the blood of older ewes could be the cause of a lessened capacity to assimilate phosphorus from diet as the age of animals rises (BLOOD and RADOSTITS, 1993). KANEKO (1997) quotes that the serum phosphate may be higher in younger animals because the growth hormone increases renal phosphate resorption. Higher concentrations of $\mathrm{K}, \mathrm{Na}$ and $\mathrm{Fe}$ in the blood of ewes up to one year old could be in connection with the rapid metabolic processes due to the increase of the body mass of ewes. With the rise of age kids (from 8 days to 6 months) the $\mathrm{Na}$ concentration drops in the blood plasma (LÖHLE, 1994).

Glucose concentration drop in the older ewes can be in connection to the weakened regeneration of glucose in the liver (CHURCH, 1993). The cholesterol circulation is influenced by the degree of stress. Therefore, higher cholesterol with age might be expected from stress of gestation and lactation. As the age rises, the concentration of total protein in the blood of sheep increases. Namely, with increasing age, the blood proteins seems to increase and it is shown in a lessend decrease of albumin concentration and a progressive increase in the globulin fraction (KANEKO, 1997).

Concerning the age influence, there has been found a statistically higher activity of AP, GGT and CK in ewes less than 1 year old. In young growing animals osseus AP is the predominant form of serum AP which decreases as maturation progresses and the epishysis closes (KANEKO, 1997). Increased CK activity in the blood serum of younger ewes could be an indicator that $\mathrm{CK}$ is a specific marker of muscle damage. With the increase of the age of ewes, the GGT activity decreased. Similar observations have been obtained by RAMOS et al. (1994).

In conclusion, on the basis of this research results it is necessary to take into consideration the age and the reproductive status of animals, before the physiological limits for the concentrations of certain blood indicators is specified in the aim of establishing the metabolic profile of the ewes. For the age, firstly there have to be taken the concentrations of P-inorganic, K, Na, Fe, glucose, cholesterol and the total proteins as well as the AP, CK, GGT activities; while for the reproductive status the concentrations of $\mathrm{Ca}, \mathrm{P}$-inorganic, $\mathrm{Na}$, albumin and the total protein as well as the ALT, CK, GGT activities. The research of the metabolic profile appliance gives basis for the regular therapy application and the carrying out the prophylactic of metabolic disturbances of ewes in the aim of reducing economy losses.

\section{References}

ALONSO, A.J.; THERESA, R.De; GARCIA, M.; GONZALEZ, J. R.; VALLEJO, M.:

The Effects of age and reproductive status on serum and blood parameters in Merino breed sheep. J. Vet. Med. A 44 (1997), 223-231 
ANTUNOVIC, Z.; BUKVIC, G.; STEINER, Z.; ANTUNOVIC, M.; RASTIJA, D.:

Dynamics of quality of the pasture and the influence to certain biochemical indicators in the blood of sheep. Krmiva 43 (2001), 301-308

ANTUNOVIC,Z.; SENCIC, D., SPERANDA, M.; LIKER, B.:

Influence of the season and the reproductice status of ewes on blood parameters. Small Ruminant Research 45 (2002), 39-44

BARANOWSKI, P.:

Certain Blood Haematological and Biochemical Indicators and Enzyme Activities in polish Merino and Polish Merino x Suffolk Ewes during Pregnancy and lactation. Animal Sci. Pap. and Rep. 13 (1995), 27-33

BARANOWSKI, P.; KMIEC, M.:

Certain blood indicators in Polish merino ewes (Wartosci prawidlowe wybranych wyskaznikow krwi polskich owiec dlugowelnistych). Zycie Weterynaryjne 9 (1997), 355-357

BAUMGARTNER, W.; PERNTHANER, A.:

Influence of age, season, and pregnancy upon blood parameters in Austrian Karakul sheep. Small Rumin. Res. 13 (1994), 147-151

BLOOD, D.C.; RADOSTITS, O.M.:

Medcina Veterinaria. $7^{\text {th }}$ ed. Interamericana. McGraw-Hill, Madrid (1993), 1293-1294.

CASTILLO, C.; HERNANDEZ, J.R.; LOPEZ, M., MIRANDA, M., GARCIA-PARTIDA, P.; BENEDITO, J. L.: Relationship between venous $\mathrm{pH}$, serum calcium and proteins in the course of anoestrus, pregnancy and lactation in the ewe. Arch. Tierz., Dummerstorf 40 (1997), 257-263

CASTILLO, C.; HERNANDEZ, J.; LOPEZ-ALONSO, M.; MIRANDA, M.; BENEDITO, J.L.:

Effect of physiological stage and nutritional management on some serum metabolite concentrations in Assaf ovine breed. Arch. Tierz., Dummerstorf 42 (1999), 377-386

CHURCH, C.D.:

Ruminant: digestive physiology and nutrition (El ruminiate: fisiología digestiva y nutrición). Acribia, Zaragoza (1993), 251-265

EL-SHERIF, M.M.A.; ASSAD, F.:

Changes in some blood constituents of Barki ewes during pregnancy and lactation under semi arid conditions. Small Ruminant Research 40 (2001), 269-277

HAMADEH, M.E.; BOSTED, H.; FAILING, K.:

Studies on relevant metabolism parameters in blood plasma of highly pregnant and nonpregnant ewes. Berliner und Munchener Tierarztliche Wochenschrift 109 (1996), 81-86

JAINUDEEN, M.R.; HAFEZ, E.S.E.:

Gestation, prenatal physiology and parturition. (Gestación, fisiología prenatal y parto). In E.S.E. Hafez (Editor), Artificial Domestic Animal reproduction and Insemination (Reproducción e Inseminación Artificial en Animales Domésticos). $5^{\text {th }}$ ed., Interamericana, México (1989), 203-224

KANEKO, J. J.: Clinical Biochemistry of Domestic Animals. $5^{\text {th }}$ ed. Academic Press., USA (1997)

KLINKON, M.; ZADNIK, T.: An outline of the metabolic profile test (MPT) in small ruminants. Stočarstvo 51 (1997), 449-454

LÖHLE, K.U.:

Untersuchungen über den Gehalt an Harnstoff, Gesamtbilirubin, Gesamtewei $\beta$ und Kreatinin im LÖHLE, K.U.: Blutplasma Afrikanischer Zwergziegen. Mh. Vet.-Med. 47 (1992), 487-493

Die Blutbestandteile Natrium, Kalium, Kalzium, Chlorid und Phosphat bei Afrikanischen Zwergziegen im Vergleich zu Literaturergebnissen, bezogen auf andere Ziegenrassen und Schafe. Mh. Vet.-Med. 49 (1994), 85-91

McNEILL, D.M.; MURPHY, P.M.; LINDSAY, D.R.:

Blood lactose v. milk lactose as a monitor of lactogenesis and calostrum production in Merino ewes. Aust. J. Agric. Res. 49 (1998), 581-587

MILLIGAN, L.P.; GROVUM, W.L.; DOBSON, A.:

The effects of sex hormones, pregnancy and lactation on digestion, metabolism, and voluntary food intake. In: Control of Digestion and Metabolism in Ruminants. Prentice-Hall, New Jersey (1986), 420435

OKAB, A.,B.; MEKKAWY, M.Y.; ELBANNA, I.M.; HASSAN, G.A.; EL-NOUTY, F.D.; SALEM, M.H.: Seasonal changes in plasma volumen, adrenocortical hormones, osmorality and electrolytes during pregnancy and parturition in Barki and Rahmani ewes. Indian Journal of Animal Sciences 62 (1992), 302-306

PASTRANA, R.; McDOWELL, L.R.; CONRAD, J.H.; WILKINSON, N.S.: Macromineral status of sheep in the Paramo region of Colombia. Small Rumin. Res. 5 (1991a), 9-21

PASTRANA, R.; McDOWELL, L.R.; CONRAD, J.H.; WILKINSON, N.S.: 
Mineral status of sheep in the Paramo region of Colombia. II. Trace minerals. Small Rumin. Res. 5 (1991b), 23-34

RAMOS, J.J.; VERDE, M.T.; MARCA, M.C.; FERNANDEZ, A.:

Clinical chemical values and variations in Rasa Argonesa ewes and lambs. Small Rumin. Res. 13 (1994), 133-139

SHINDE, K.A.; PATNAYAK, B.C.; KARIM, S.A.; MANN, J.S.:

Blood metabolites and mineral status of sheep under silvipastoral system of grazing managment. Ind. J. of Animal Sci. 65 (1995), 1077-1080

SMITH, G.M.; FRY, J.M.; ALLEN, J.G.; COSTA, N.D.:

Plasma indicators of muscle damage in a model of nutritional myophathy in weaner sheep. Aust. Vet. J. 71 (1994), 12-17

STATISTICA:

StatSoft, Inc. (data analysis software system), version 6 (2001) www.statsoft.com.

WHITE, C.L.; TREACHER, T.; BAHHADY, F.A.:

Mineral and Vitamin Status of Sheep in Syria, Jordan and Turkey. Proceedings of a workshop (Mineral Problems in Sheep in Northern China and Other Regions of Asia), Beijing, People's Republic of China, 25-30 September 1995, 73, 61-67

YANO, F.; YANO, H.; BREVES, G.:

Calcium and phosphorus metabolism in ruminants. In: Tsuda, T.; Sasaki, Y.; Kawashima, E. (Editors), Physiological aspects of digestion and metabolism in ruminants. Academic Press, Boston, USA (1991), 277-296

Received: 2003-09-30

Accepted: 2004-05-12

Autor's address

Prof. Dr. ZVONKO ANTUNOVIĆ, D. Sc. MARCELA ŠPERANDA,

M. Sc. ZVONIMIR STEINER

University of J. J. Strossmayer in Osijek

Faculty of Agriculture

Trg sv. Trojstva 3

CRO-31000 Osijek

E-Mail: zantun@pfos.hr 